https://doi.org/10.46344/JBINO.2020.v09i03.05

\title{
THE TEACHING OF TECHNOLOGIES FOR MONITORING THE ANTHROPIC LANDSCAPE THROUGH THE DEVELOPMENT OF THE INTERNET OF THINGS
}

\author{
P. D'Antonio'*', V. N. Scalcione², \\ 'School of Agricultural, Forestry, Food and Environmental Sciences, University of Basilicata, Potenza, Italy; ${ }^{2}$ University of Basilicata, DISU,
} Potenza, Italy

This reflection is placed in the strategic spaces for meeting the world of new technologies, thus responding to an increasingly felt need, not only in research institutions, but also in the business world and in the governance of the territories, to make arranges the necessary interactions between knowledge, for the promotion of innovation on a human scale, and, ultimately, for a dialogue between disciplines, which favors the promotion of a humanism of technologies. With these objectives, the creation of a Green Information System (SIV) is proposed, a more or less complex decision support tool, which will consist of an implementable, updatable, query able and georeferenced data platform. Specifically, the design activity will be aimed at monitoring the state of the vegetation.

In the SIV system additional information such as the opening hours of parks and gardens, areas equipped for disabled people, children, pets, location of services, etc. can be inserted. A monitoring system will be added to the monitoring system, integrated with progressive numerical detection and traceability tools. The traceability tools will be provided in the access and / or exit areas of the parks and will allow to estimate in real time the number and spatial distribution of tourists and on the basis of these, to plan solutions for the use of the individual areas.

Everything is consistent with the intent to encourage the affirmation of a new digital citizenship, capable of supporting the actions implemented with the intent to promote the involvement of administrations and citizens. These actions will be defined through the design of tools that make our natural / cultural / anthropic landscapes accessible through the use of smart objects. In a perspective that aims to bring about innovation through the interaction between the areas, for an innovation that is an authentic opportunity for growth for social coexistence as a whole, attention to issues related to innovation and process evaluation in fact, it requires using a repertoire of tools that take into consideration the intrinsic components of skills, such as aspects of learning and evaluation processes with their specific characteristics, with the specific aim of structuring design methods capable of determining skills, achieving budgeted results allow self-improvement. These objectives will be defined, during the project phases, through the realization of activities expressing the following purposes:

- educate on the use of the Internet of Things, of intelligent objects that - 
according to Gardner's estimates - will populate our cities in the near future;

- promoting the protection and promotion of the quality of the territories, through the development of digital skills, that is, a vast set of basic and specialized technological skills, to be used in reskilling training contexts, as well as for a conscious use of "smart objects"'" ;

- carry out research activities capable of promoting collaboration between stakeholders in the context of promoting the teaching of innovative technologies, with particular reference to training contexts.

- develop and apply multimedia technologies to innovate the methods of planning and assessment of learning; • to encourage multidisciplinary teaching and research aimed at achieving an authentic assessment, produced by a lasting understanding of disciplinary and transversal knowledge and skills, at the basis of innovations capable of affecting learning contexts and the definition of cognitive contexts. In order to carry out the aforementioned activities, it is necessary, during the realization of the project, of a researcher, who will proceed to the design and implementation of the aforementioned steps.

- educate on the use of the Internet of Things, of intelligent objects that according to Gardner's estimates - will populate our cities in the near future;

- promoting the protection and promotion of the quality of the territories,

\footnotetext{
Smart objects, connected to the network and interconnected with each other, capable of acquiring, exchanging and analyzing a huge amount of data in order to develop the best operational strategies.
}

through the development of digital skills, that is, that vast set of basic and specialized technological skills, to be used in reskilling training contexts, as well as for a conscious use of "smart objects"

- carry out research activities capable of promoting collaboration between stakeholders in the context of promoting the teaching of innovative technologies, with particular reference to training contexts.

- develop and apply multimedia technologies to innovate the methods of planning and assessment of learning;

- to encourage multidisciplinary teaching and research aimed at achieving an authentic assessment, produced by a lasting understanding of disciplinary and transversal knowledge and skills, at the basis of innovations capable of affecting learning contexts and the definition of cognitive contexts. In order to carry out the aforementioned activities, it is necessary, during the realization of the project, of a researcher, who will proceed to the design and implementation of the aforementioned steps.

\section{REFERENCES}

Albert, M., (2015). Seven Things to Know about the Internet of Things and Industry 4.0.

Axmann, B., (2016). Digital factory industry 4.0 (motivation, challenges and solutions). ZWF Zeitschrift fuer Wirtschaftlichen Fabrikbetrieb, 111 (3), pp. 143-147.

Cardinale D., D'Antonio P., Moretti N., Scalcione V. N., (2020). Risk perception in forest utilizations: experimental analysis in the Basilicata forest sites, Journal of Forestry, wild life and Environment, Vol. 1, Issue 1. 
Castoldi M., Scalcione V. N., (a cura di), Competenze di cittadinanza e valutazione del contesto educativo, Scalcione V., Valutazione degli apprendimenti- progettazione didattica - miglioramento scolastico, Editore Anicia, Roma 2019, ISBN 9788867094387

D'Antonio P., Scalcione V. N., (2020). Digital Humanities: ICT for a Teaching of Inclusion, Agricultural Research \& Technology, Volume 23 Issue 4.

\section{D'Antonio P., Scalcione V. N., D'Antonio} C.. Sustainable urban green management systems: battery powered machines and equipment. International Journal for Research in Agricultural and Food ScienceVolume-6 | Issue-3 March,2020

D'Antonio P., Scalcione V. N., (2020). Software and satellite technologies for precision agriculture: the potential with the $5 \mathrm{~g}$ network, EPH - International Journal of Agriculture and Environmental ResearchVolume-6 I Issue-3 March,2020

D'Antonio P., Scalcione V. N., Romano F., (2020). The use of satellite technology for digital citizenship: experimental tests and investigation methods, International Journal of Food Science and Agriculture, Vol. 4, Issue 1.

Scalcione Vincenzo N., Le nuove tecnologie nella didattica Apprendimento on line e didattica inclusiva, Editricermes Potenza 2016-ISBN 9-788898-321278

Scalcione Vincenzo Nunzio, Experiential Learning and Educational Tools for Selfevaluation in the School, Polish journal of Educational studies ISSN 2657-3528, 2019 Scalcione Vincenzo, Indicatori di qualità e authentic assessment - la progettazione degli strumenti per la valutazione autentica in Curcio Gennaro, Scalcione Vincenzo, Cittadinanza e dialogo intraculturale. Educare per includere e promuovere la valutazione autentica, Editore Aracne, Roma 2019 ISBN 978-88-255-25554-0.

Sohne W., Heinze O., Groten E. (1994). Integrated INS/GPS System for High Precision Navigation Applications. Record-IEEE PLANS, Position Location and Navigation Symposium, 35(2): 310-313.

Xiangjian, M. and Gang, L. (2007). Integrating GIS and GPS to Realise Autonomous Navigation of Farm Machinery. New Zealand Journal of Research, 50(1), 807-812.

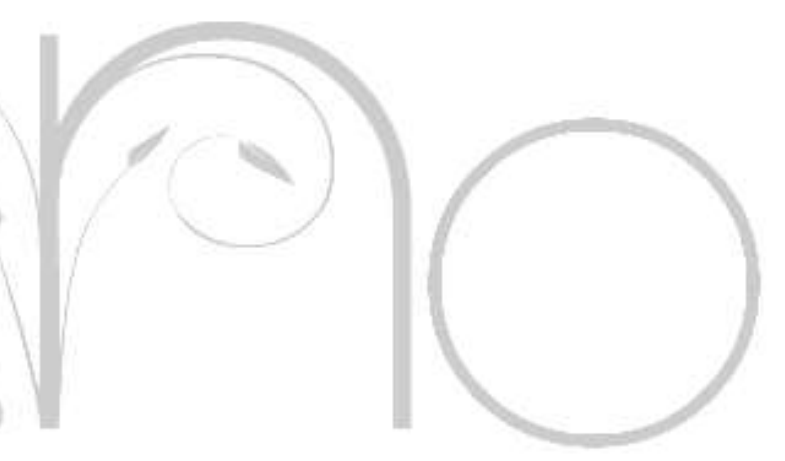

